\title{
Accountability key for patient charter
}

Published at www.cmaj.ca on Feb. 23

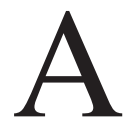
patient-centred charter for quality must have adequate accountability measures if it is to result in improvements in Canada's health care system. That appeared to be the general consensus of Canadian medical leaders attending a special session of the fourth annual CEO Forum (Metrics for Healthcare Quality: The Leader's Role) in Montréal, Quebec, on Feb. 17.

"I think a charter is a very good patient-first mechanism to articulate system goals," says Dr. Martin Vogel, chief executive officer of the Saskatchewan Medical Association.

But simply drafting a charter and leaving it at that will do little good, Vogel warns. For a patient charter to be effective in improving health care, he says, it would have to go through a five-step process: drafting, acceptance, compliance, accountability and consequences.

"How far down the list are you going to go?" says Vogel. "You can draft a charter and put it out there and it will just be a bunch of motherhoodand-apple-pie statements."

Vogel was not alone in his opinion that a charter that can be ignored without consequence will be just that ignored.

A toothless charter might look nice framed and mounted in an elevator, but wouldn't amount to much, if anything, says Judith Shamian, president and chief executive officer of the Victorian Order of Nurses, a nonprofit dedicated to home care and community services, and another audience member at a panel discussion on "Working Toward a Charter for Quality in Healthcare."

"Having a charter on its own will have zero effect," she says. "I worry that it will mean a lot of discussion and debate instead of getting down to brass tacks and doing what needs to be done."

Even members of the three-person panel expressed reservations about

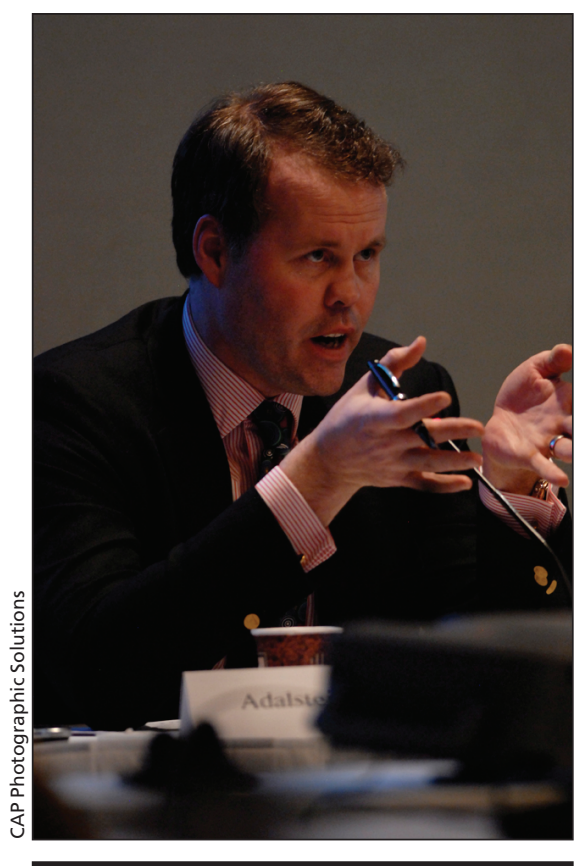

The creation of a patient-centred charter for quality in health care would provide clarity on what needs to be fixed about Canada's health care system, says Adalsteinn Brown, assistant deputy minister of the Health System Strategy division of Ontario's Ministry of Health and Long-Term Care.

putting too much work into creating a patient charter on quality of care. Bonnie Brossart, chief executive officer of the Health Quality Council in Saskatchewan, said that the idea of a charter was a good one, but that the effort required to create it might be better put elsewhere.

"While I don't necessarily disagree with the intent and the concept and the potential benefits of a patient charter of rights, I'm not sure I would start there," she said during her presentation. "While a charter may enable a one-stop, singlesource document to specific patient rights and may be seen, as it has in other jurisdictions, to provide the mechanism to voice concerns, I personally don't have a clear line of sight of how this would readily result in delivering patient-centred care system-wide."

Another panelist — Dr. Robert
Ouellet, past-president of the Canadian Medical Association - said that the mere development of charter is not the goal; supporting mechanisms to ensure accountability are also necessary. These would include the development of metrics to measure and report on elements of the charter, and the creation of incentive programs for patients, providers and administrators, he noted.

"The charter itself is our dream house," Ouellet said during his presentation (in remarks translated from French to English). "We have to decide how to build it and how to finance it."

The third and final panel member Adalsteinn Brown, assistant deputy minister of the Health System Strategy division of Ontario's Ministry of Health and Long-Term Care - may have been the most optimistic. The very creation of a charter, he said, would provide clarity on what needs to be changed about the health care system.

"I believe we can at least articulate minimum expectations at the nation level," Brown said in response to an audience question.

He also noted that Canada would not be the first country to create a patientfocused charter or comparable document. Australia, for example, has the Australian Charter of Healthcare Rights (www.health.gov.au/internet/safety/pub lishing.nsf/Content/PriorityProgram-01). And New Zealand has The Code of Health and Disability Services Consumers' Rights (www.hdc.org.nz/theact /theact-thecode).

"There is a late-mover advantage," Brown said during his presentation. "We can learn from what other jurisdictions have done."

The forum was presented by the Canadian Health Services Research Foundation, the Canadian Medical Association and the Association of Canadian Academic Healthcare Organizations (www.chsrf.ca/CEO_forum2010 _e.php). — Roger Collier, CMAJ

DOI:10.1503/cmaj.109-3192 